Vol. 122006 pp. 25-30

\author{
Andrzej Harasimiuk, Ewa Tarchalska, Andrzej Pałgan \\ Department of Geoecology \\ E-mail: a.harasimiuk@uw.edu.pl
}

\title{
SOIL-GEOCHEMICAL ASPECTS OF LAND USE IN ABANDONED LAND IN CENTRAL POLAND
}

\begin{abstract}
It is observed increasing of abandoned land in Poland in last decade of $20^{\text {th }}$ century. The part of abandoned land is usually covered by birch tree community. The entrance of birches, especially on pure sandy area, changes properties of soil. The samples of soil horizons, litter in different stages of decomposition and leaves from birch trees, were taken into analysis. The role of birch was analysed also in comparison to arable land, abandoned land without trees and different ages birch trees communities. After the entrance birch trees soil profiles were enriched in nitrogen and elements such as aluminium, iron, cadmium, lead, cobalt, zinc, which were moved from soil or come from atmospheric load and were accumulated in litter or humus horizon. Compared to arable land, some elements (for example calcium) had lower concentration under birch trees. After several years without fertilization the relationship between elements were changed. In early stages (until 10 years) in litter horizons potassium prevails calcium, later - calcium prevails potassium. Birch trees made soil environment more natural compared to arable land.
\end{abstract}

Key words: abandoned land, birch, pine, plant and soil relationship.

\section{INTRODUCTION}

In the last decade of the $20^{\text {th }}$ century, the changing relationships between soils and vegetation involved an increasing share of fallow land. In 1990, the total acreage of fallow land was 0.16 million hectares (which accounted for $1.1 \%$ of total farmland); in $2000-1.67$ million hectares $(9.2 \%)$, and in 2002 it reached 2.30 million hectares (17.6\%), which meant that nearly every fifth hectare was uncultivated.

The transformation of plant cover in former farmland proceeded in two basic directions: natural occupancy through self-seeding of trees and bushes - mainly birch, and through anthropogenic transformation through plantings - mainly pine (Bernardzki, Kowalski 1983; Rutkowski 2001; Grzywacz 2002). Both the natural process and anthropogenic afforestation in some of the fields led to the formation of a category of transformed farming landscape, with a mosaic structure of plantings and arable land (Szujecki 1996; Rykowski 
1990). The introduction of arborescent species can affect the properties of the soil environment, such as changes in nutritional requirements, humidity conditions or transfer of elements (Karlsson 1998). For these reasons, this issue was considered an interesting topic for research, which focused on the impact of pine and birch communities on properties of soil.

\section{THE RESEARCH AREA AND METHODS}

Two research plots, involving about a dozen fields located about $40 \mathrm{~km}$ east of Warsaw, near the villages of Stanisławów and Cisie, were covered by the study. These are areas with fields of fluvioglacial sands, which are windswept in some places, forming dunes. The area is predominantly flat, with weak valley depressions caused by small watercourses. Podzolic soils prevail, with patches of podzol and rusty soil, of a low bonitation class ( $V$ and VI). As a result, the process of discontinuing the use of land for farming purposes is increasingly stronger in these areas. Here, the abiotic conditions can be regarded as relatively homogenous, which allows for a comparative analysis involving the age and structure of plant communities. The neighbouring research plots were selected in the following types of areas: those occupied by birch communities, within an area of prevalent pine plantings, and, for comparison, those within arable land still under cultivation. These were communities characterized by different ages (between 5 and 40 years) and in different stages of secondary succession.

The measurements of the basic physical properties were made, the phytosociological structure was identified (birch communities), and samples of soil and plants were collected (samples from the mineral soil levels, forest litter in different decomposition stages, as well as forest leaves and needles). In the collected soil and plants samples, the following parameters were determined: $\mathrm{pH}\left(\mathrm{H}_{2} \mathrm{O}\right.$ and $\left.\mathrm{KCl}\right), \mathrm{N}, \mathrm{P}$ and $\mathrm{K}$, using standard chemical analysis methods (Ostrowska 1991). In the extracts $(10 \% \mathrm{HCl}$ for plants and $20 \% \mathrm{HCl}$ for soils), a number of elements were determined using the ICP-MS method (e.g. $\mathrm{Ca}, \mathrm{Mg}, \mathrm{Al}, \mathrm{Fe}, \mathrm{Mn}$ and heavy metals).

\section{THE RESULTS AND DISCUSSION}

Soil cultivation lasting many years leads to negative changes in the soil profile. As regards physical properties, this is manifested by the occurrence of the so-called plough sole (a compacted layer at the depth of $30-50 \mathrm{~cm}$ ). Arborescent species occupying former farmland show a varied capacity to penetrate this layer. Pine trees handle this situation rather poorly, and as a result are forced to expand their roots horizontally, within the former arable and humus layers. This leads to a reduced use of nutrients and the appeararce of degradation symptoms in the pine monocultures which are 
30 or 40 years old (trees fall-out, root fungus). There is no problem of compacted layer in the case of spontaneous occupancy in former farmland by birch trees or broadleaf additions in pine plantations (mainly oak), where tree roots reach deeper, beyond the compacted layer. In such a situation, the soil resources are more efficiently used, with a lower incidence of tree diseases.

The termination of mineral fertilizing leads to a changes in the chemical properties of soils (Table 1). The nutrients from the humus level are depleted and transported by plants to the forest litter level. The chemical regime of soils changes, so as the distribution of elements in the soil profile.

Table 1.

Basic chemical properties of soils depending on the type of plant cover

\begin{tabular}{|c|c|c|c|c|c|c|c|}
\hline \multirow{2}{*}{$\begin{array}{l}\text { Stanisławów plot } \\
\text { - types of land cover }\end{array}$} & \multirow{2}{*}{$\mathrm{pH}\left(\mathrm{H}_{2} \mathrm{O}\right)$} & \multirow{2}{*}{$\mathrm{pH}(\mathrm{KCl})$} & $\mathrm{N}$ & $\mathbf{P}$ & $\mathrm{K}$ & $\mathrm{Ca}$ & $\mathrm{Mg}$ \\
\hline & & & $\%$ & \multicolumn{4}{|c|}{$\mathrm{mg} / 100 \mathrm{~g}$} \\
\hline \multicolumn{8}{|c|}{ Humus horizon } \\
\hline Arable field & 4.3 & 3.5 & 0.10 & 48.0 & 40.0 & 45.9 & 35.3 \\
\hline Pine plantings ( 15 years old) & 4.1 & 3.8 & 0.06 & 24.0 & 36.2 & 30.9 & 36.1 \\
\hline $\begin{array}{l}\text { Degraded pine plantings } \\
\text { ( } 35 \text { years old })\end{array}$ & 4.4 & 3.7 & 0.05 & 20.0 & 27.7 & 34.6 & 27.8 \\
\hline $\begin{array}{l}\text { Pine plantings with oak } \\
\text { ( } 35 \text { years old) }\end{array}$ & 4.4 & 3.9 & 0.05 & 16.0 & 26.9 & 24.9 & 26.0 \\
\hline Birch wood (5 years old) & 4.7 & 3.9 & 0.09 & 31.0 & 50.4 & 83.4 & 69.7 \\
\hline Birch wood (20 years old) & 4.4 & 3.7 & 0.12 & 32.8 & 60.0 & 82.6 & 82.8 \\
\hline \multicolumn{8}{|c|}{ Forest litter horizon } \\
\hline Pine plantings ( 15 years old) & 4.4 & 3.6 & 1.43 & 112.5 & 152.0 & 2552.0 & 369.5 \\
\hline $\begin{array}{l}\text { Degraded pine plantings } \\
\text { ( } 35 \text { years old) }\end{array}$ & 4.0 & 3.0 & 0.34 & 45.0 & 24.4 & 206.0 & 139.0 \\
\hline $\begin{array}{l}\text { Pine plantings with oak } \\
\text { ( } 35 \text { years old) }\end{array}$ & 4.0 & 3.4 & 1.60 & 105.0 & 82.0 & 1413.0 & 345.9 \\
\hline Birch wood (5 years old) & 6.6 & 5.8 & 2.20 & 160.0 & 272.0 & 1900.0 & 311.9 \\
\hline Birch wood (20 years old) & 6.2 & 5.7 & 2.20 & 170.0 & 192.0 & 2093.2 & 260.1 \\
\hline \multicolumn{8}{|c|}{ Leaves/needles (median values) } \\
\hline Pine needles & 5.5 & 5.1 & 5.10 & $\mid 162.5$ & 648.0 & 1995.0 & 636.7 \\
\hline Birch leaves & 5.5 & 5.0 & 2.8 & 236.7 & 1046.7 & 1440.0 & 557.8 \\
\hline
\end{tabular}

In the areas occupied by birch communities, a higher degree of complexity in the matter circulation cycle can be observed than in land under agricultural use. Most changes are visible in the topsoil horizons, while heavy metals and toxic elements (clays) are absorbed and accumulated in the soil organic horizons. Under the birch communities of 5 and 20 years old, the lead content in the upper soil layers was higher than that under wasteland and arable land. Young communities are particularly exposed to toxic factors, whereas in older communities the process of self-melioration takes place, as a result of which the lead content in the upper soil horizons is lower than in younger communities. 

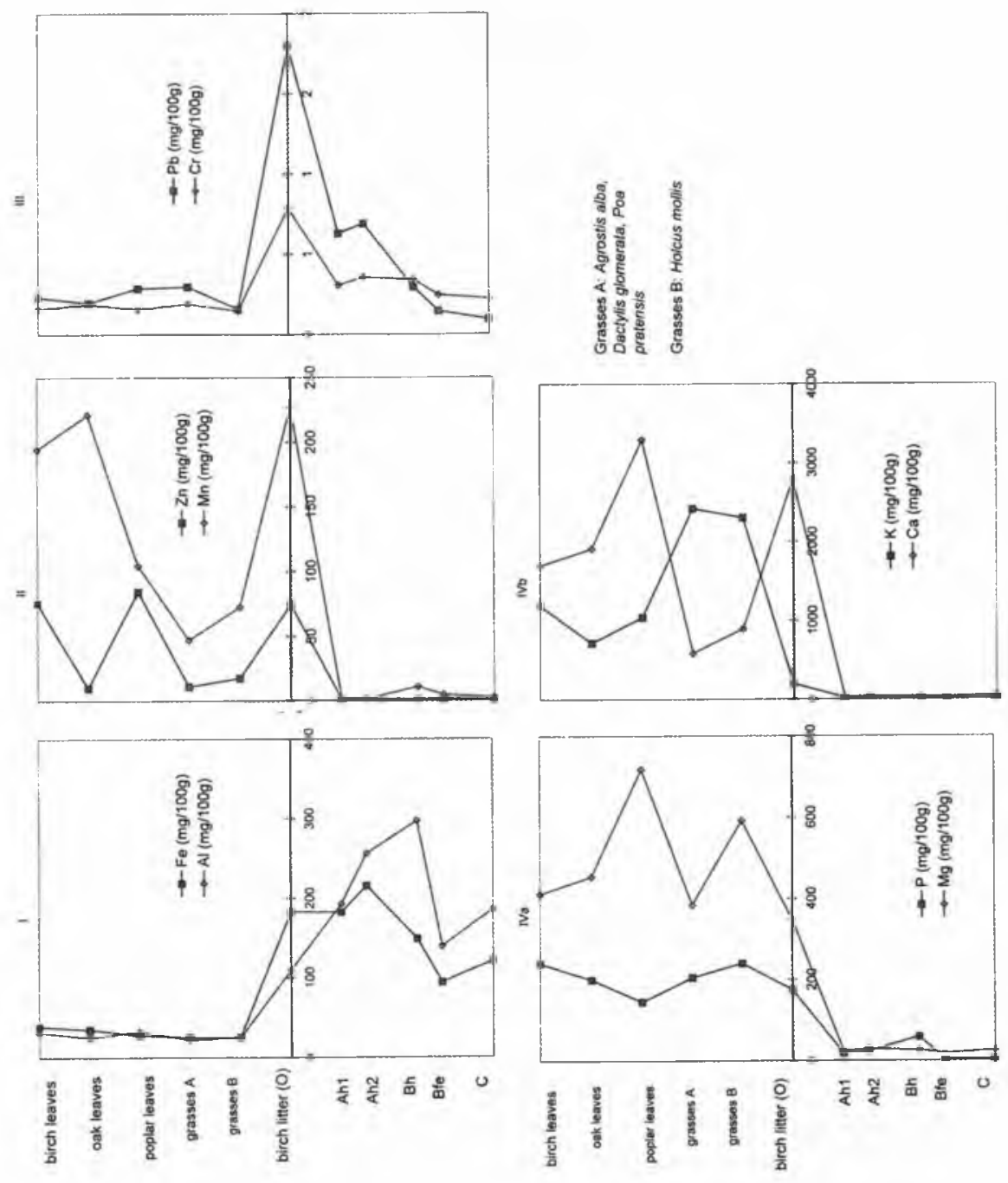

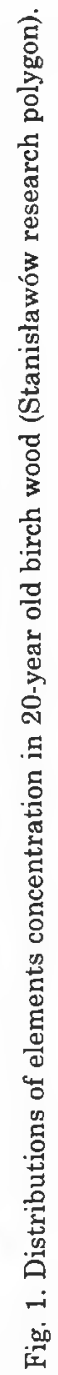


When agricultural use is discontinued, the quantity of calcium in the upper soil horizons will fall rapidly, both under birch wood and wasteland, and will stabilize at a similar level throughout all the soil profile horizons. No distinct changes in the distribution of aluminium and iron in the soil profiles under birch wood have been observed, as compared to waste and arable land.

Within birch communities, several types of vertical distribution of elements can be distinguished:

I. High concentration of elements in the mineral horizons. It mainly involves such elements as $\mathrm{Al}$ and $\mathrm{Fe}$, which occur in the parent material, and the soil is the source from which these elements are uptaken and transported upwards in the plants.

II. High concentration of elements in the organic matter (forest leaves and the litter layer) and low concentration at the grassy undergrowth layer. This involves $\mathrm{Zn}$ and $\mathrm{Mn}$ - elements which play an important role in the structure and functions of leaves.

III. High concentration in the upper soil layers (forest litter and humus layers); it involves organic substances with a high sorption capacity, and applies to $\mathrm{Pb}$ and $\mathrm{Cr}-$ elements which are the first to be absorbed. Unlike $\mathrm{Zn}$ and $\mathrm{Mn}$, these are not elements which are desired by plants.

IV. This type is characteristic of biophilous elements, which are accumulated in plant organs and following leaf (needle) shedding, they penetrate into the soil (variant IVa $5 \mathrm{a}$ for $\mathrm{P}$ and $\mathrm{Mg}$ ) or are absorbed in opposing ways (variant IVb for $\mathrm{K}$ and $\mathrm{Ca}$ ).

\section{CONCLUSIONS}

Owing to a significant share of abandoned land and the regulations adopted as a result of Poland's accession to the EU, the problem of environmental changes in these areas will be more and more pertinent. In the land which was fallowed on a mass scale in the 1990s, plant communities with relatively well-developed structures will evolve, which will substantially affect the most susceptible components: soils, as well as water and microclimatic conditions. In light of the above, it seems that the environmental changes related to fallowing and wider introduction of broadleaf species into the forest structure should be monitored (Harasimiuk 1998). 


\section{REFERENCES}

Bernadzki E., Kowalski M., 1983, Brzoza na gruntach porolnych [The Birch in Former Farmland, in Polish], Sylwan, 127, 12; 33-43.

Grzywacz A., 2002, Problemy zalesień w wielofunkcyjnym rozwaju obszarów wiejskich [Afforestation Issues in the Multifinctional Development of Rural Areas, in Polish] Post. Nauk Roln., 3; 15.

Harasimiuk A. 1998, Naturalne użyźnianie krajobrazu, jego uwarunkowania i wplyw na sukcesję zbiorowisk roślinnych [Natural Landscape Fertilization, Its Conditions and Impact on the Succession of Plant Communities, in Polish], Przeglad Geograficzny, 70, $3-4 ; 305-314$.

Karlsson A. (et al.), 1998, An Analysis of Successful Natural Regeneration of Downy and Silver Birch on Abandoned Farmland in Sweden, Silva Fennica, 3; 229-240.

Ostrowska A., Gawliński S., Szczubialka Z. 1991, Metodyanalizyioceny właściwości gleb i roślin [Methods of Analysing and Determining Soil and Plant Properties, in Polish]. Institute of Environmental Protection Catalogue.

Rutkowski P., 2001, Problemy doboru składu gatunkowego do zalesień gruntów porolnych [Problems of Species Selection in Former Farmland Afforestation, in Polish], Roczniki Akademii Rolniczej w Poznaniu, Leśnictwo, 39; 233.

Rykowski K., 1990, Problemy ochrony lasu na gruntach porolnych [Problems of Forest Protection in Former Farmland, in Polish], Sylwan, 157, 3-12; 75-89.

S zujecki A., 1996, Ekologiczne aspekty odtwarzania lasu na gruntach porolnych [Ecological Aspects of Forest Regeneration in Former Farmland, in Polish], Prace IBL. series B, 27; 47-56.

English translation: Dorota Szmajda 